\title{
Chapter 16 \\ Mediation and Conciliation in Collective \\ Labor Conflicts in Australia
}

\author{
Mark Bray and Johanna Macneil
}

\subsection{Case Study: New South Wales (NSW) Trains}

In January 2018, Australia's national industrial relations tribunal, the Fair Work Commission ("the Commission"), mediated a high profile dispute between railway workers and management in New South Wales (NSW), the most populous of Australia's states.

Most of the rail workers were represented by two unions, Professionals Australia (covering professionals and managers), and the Rail, Tram and Bus Union (RTBU). These unions, with some smaller unions and supported by the union peak body, bargained as a single group, the Combined Rail Unions (CRU). The employers, Sydney Trains and NSW Trains, were both government owned and also bargained together.

The dispute formally began in July 2017 when, in the collective bargaining process, the CRU presented to employers an initial list of demands for improved wages and working conditions. Management responded with their own demands. Subsequent negotiations were conducted almost weekly.

A failure to agree on a number of central issues (including pay increases, redundancy and redeployment provisions, and rosters) led the parties to seek the intervention of the Fair Work Commission. This came through four separate actions, involving three different tribunal members on the panel responsible for the transport industry.

First, in mid-November, the CRU made an application for a 'good faith bargaining' (GFB) order. In other words, the unions sought an order to require the employers to bargain as required in the legislation, including disclosing relevant information

M. Bray $(\bowtie) \cdot$ J. Macneil

Newcastle Business School, The University of Newcastle, Callaghan, Australia

e-mail: mark.bray@newcastle.edu.au

J. Macneil

e-mail: johanna.macneil@newcastle.edu.au

(C) The Author(s) 2019 
in a timely manner. The CRU argued that the employers were withholding information about past productivity changes and future restructuring, both of which would inform the amount of the wage increase they could seek. The first step in the formal application was heard before the Commission in early December, with a subsequent hearing scheduled for 30-31 January.

Second, just days after the GFB application, the unions applied to the Commission for permission to undertake protected industrial action. Permission was granted and subsequent ballots amongst members gained support in 2 of the 7 unions, including the RTBU. On the basis of this support, the RTBU announced its intention to impose an overtime ban commencing on 25 January, with an all-out strike planned for 29 January.

Third, the employers made a counter GFB application, claiming the unions were not themselves negotiating in good faith, and seeking assistance from the Commission in the form of conciliation. This application led to a series of conciliation conferences. Some, but not sufficient, progress was made.

In mid-January, the dispute came to a head. Public pressure on government had been building because of failures on the Sydney train network. Extreme temperatures, lightning strikes during storms, the introduction of a new timetable and staff shortages left thousands of commuters stranded when trains were cancelled. The threat of further disruption due to the planned industrial action gained huge media attention. The employers made further concessions, which the union leadership put to its members, along with a recommendation to call off the planned strike. Union delegates rejected both the employers' offer and the proposal to end industrial action. The planned ban on overtime started on 25 January.

This led to the fourth intervention by the Commission. Following an application by the employers, along with the responsible government minister, an order to terminate or suspend the strike was made, the tribunal member being satisfied that the industrial action represented, amongst other things, "a threat to life, safety, health or welfare of people, significant damage to the Australian economy, or a significant part of it". On 28 January, the industrial action was ordered suspended until March. The strike did not take place.

Negotiations continued along with further conciliation conferences in early February, with the employers making an amended offer, including several improvements in pay and conditions. Both sides agreed to take the new proposal to employees/members. It was subsequently accepted and approved by the Commission in April 2018, resulting in two legally-binding collective agreements, one for Sydney Trains and one for NSW Trains.

\subsection{Introduction}

Industrial relations in Australia have seen dramatic change over recent decades, but (as can be seen in the NSW trains case), the mediation of collective labor conflict continues to be dominated by the state and its agencies. There has been modest 
involvement of private mediators. This means there is considerable institutional continuity, making both history and the law especially important in understanding the nature of mediation in Australia.

The story of mediation of collective labor conflict presented in this chapter comes in two parts. Before the $1990 \mathrm{~s}$, mediation came almost totally through a system of compulsory conciliation and arbitration, in which industrial tribunals worked to manage the conflict between employers and unions, in both disputes of interests and disputes of rights. Tribunals also assumed a pervasive regulatory role within a broader system of industrial relations, which was heavily collectivised and increasingly centralised. This broader industrial relations system, and the role of tribunals within it, was widely considered exceptional in international terms.

From the 1990s onwards, however, the old system was jettisoned in favor of greatly expanded individual employment rights and decentralised collective bargaining. This brought Australian industrial relations much closer to its Anglo-American counterparts. The mediation of collective conflict by industrial tribunals remained important and the tribunals retained much of their institutional form and even individual membership. However, the functions of these tribunals changed dramatically. They lost much of their regulatory role and their mediation role narrowed to a more conventional pattern, focusing on procedural aspects of disputes of interests and the performance of voluntary mediation and/or arbitration of disputes of rights.

Before embarking on the details of this story, however, there are some key definitional issues to address.

First, consistent with the 'phases' model set out in this book's appendix, we assume that conflict inevitably underlies the employment relationship, remaining latent or at least low-level most of the time. This conflict sometimes emerges more actively, manifesting in specific forms over specific issues at different places and times. Particularly important is the distinction between individual and collective manifestations of conflict, the latter being the main focus of this book. We therefore see 'conflict' as a general term, while in this chapter we prefer to refer to specific manifestations as 'disputes'. This latter term, however, is socially constructed and its meaning varies according to circumstances. In Australia, 'dispute' has both a specific legal and a statistical definition, further explained below, as well as a more general, 'common sense' meaning.

Second, we recognise a distinction between disputes of interests and disputes of rights. The former involves disagreements between the parties over the creation of rules to the employment relationship, while the latter are disagreements over the application or interpretation of existing rights.

Third, the term 'mediation' is rarely used in Australian industrial relations. The term only appeared in legislation for the first time in 1996 (Spencer \& Altobelli, 2005: 5), to identify the new opportunity for disputing parties to use private dispute resolution providers, but was left undefined. The more common term is conciliation (Foenander, 1959: 89-91; Spencer \& Altobelli, 2005: 5). The Commonwealth Conciliation and Arbitration Act 1904 governed the prevention and settlement of industrial disputes until its repeal in 1988. Section 20 of the Act did not define 'conciliation' but instead described the role of the Commission as including the 
encouragement of settlement of disputes, requiring (in Section 26) that "where an industrial dispute has been referred for conciliation by a member of the Commission, the member shall do all such things as appear to him to be right and proper to assist the parties to reach an agreement on terms for the prevention or settlement of the dispute" [authors' italics]. Where conciliation was not effective, the dispute was referred (to a different member) for compulsory arbitration.

Despite the lack of definitions, the way in which conciliation is understood in Australian industrial relations is consistent with the broad meaning given to 'mediation' in this book, so that is the definition we use; that is, any third party assistance to help parties prevent escalation of conflict, end their conflict, and find negotiated solutions to their conflict.

\subsection{How Is Mediation Organised and Conducted?}

The mediation of collective labor conflict in Australia has long been the preserve of the state. Even in more recent times, when the broader industrial relations system has become more market-based, the long history of state intervention (only briefly outlined in this section) continues to exert a strong influence. This is evident not only in the legal and other formal aspects of industrial relations, but also in the attitudes and behaviors of the parties.

\subsubsection{Historical and Legal Context}

After many thousands of years of occupation by the indigenous aboriginal peoples, white Europeans settled permanently on the continent now called Australia in 1788, establishing a British colony where the city of Sydney now stands. Other British colonies were subsequently established elsewhere, before they federated to create the modern nation of Australia in 1901. The terms of this federation were embodied in a formal Constitution determining the respective powers of the new federal and State parliaments. In 1901, the population of Australia was around 4 million, growing to around 24.5 million in 2017. The Australian economy was historically reliant on agriculture and mining, although manufacturing grew significantly during the 20th century to peak in the 1960 s, largely as the result of protection from international competition afforded by tariffs on imported goods. The virtual elimination of tariff barriers was one part of a broader 'deregulation' of the Australian economy in the 1980s onwards, as neoliberal ideas gained popularity.

Consistent with the British tradition, employee representation in Australian industrial relations has always focused on one channel—namely, trade unions. There have been few laws promoting non-union channels and no history of works councils as is common in Europe (Bray, Waring, Cooper, \& Macneil, 2018: Chap. 7). Moreover, relations between employers and unions have generally been adversarial, despite 
many attempts to promote cooperation, via government policy and law as well as private initiative (Bray et al., 2017: Chap. 3).

\section{Compulsory conciliation and arbitration}

From around the turn of the 20th century, corresponding roughly with the beginning of the federation, the state intervened extensively in collective labor conflict through a system of compulsory conciliation and arbitration (see generally Macintyre \& Mitchell, 1989). The emergence of this system was usually explained as a political response to highly disruptive industrial disputes (a combination of strikes and lockouts) during the $1890 \mathrm{~s}$, in the context of a small and geographically isolated nation struggling to develop economically. The continued survival-indeed, the robust operation - of the system over subsequent decades until the 1990s was variously attributed to its ability to meet the interests of most sectoral stakeholders, the 'flexibility' of the tribunal as an organization, and the capacity of individual tribunal members to adjust to suit the times (see generally Isaac \& Macintyre, 2004). Few other developed countries have witnessed such deep and persistent intervention in industrial relations by the state, while only New Zealand has seen similar intervention undertaken by industrial tribunals (Walker, 1984).

In general terms, the compulsory conciliation and arbitration system meant that wherever collective labor conflict (in the form of disputes, over either interests or rights) occurred, statutory bodies (originally in the form of courts, but subsequently industrial tribunals) were obliged by law to intervene. To begin, the tribunals convened meetings (or 'conferences') of the parties involved, attendance at which was compulsory. At these conferences, the tribunals tried to conciliate a resolution of the dispute. Failure to achieve resolution resulted in the tribunals convening compulsory arbitration hearings with the parties, potentially leading to determinations by the tribunals which were imposed upon the parties, thereby 'settling' the dispute.

Within these simple parameters, there was great complexity in the practice of compulsory conciliation and arbitration for at least four reasons.

First, despite the system continuing in broadly similar terms for around 80 years until the early 1990s, there were many changes in legal provisions and practical operation. Second, while it is easy to consider it as a single system, it was in fact highly fragmented because of Australia's federal system of government. Industrial tribunals were established and operated not only within the federal jurisdiction but also within the six State jurisdictions, each with its own legal and institutional idiosyncrasies. Third, there were significant shifts over time in the relative importance of the various jurisdictions, with the systems in the six States initially being most important but gradually giving way to the federal system.

Fourth, the practice of compulsory conciliation and arbitration in each jurisdiction was complicated. For example, the functions of the industrial tribunals became much broader than the system's architects anticipated. In particular, the tribunals came to perform a regulatory function rather than simply mediating conflict, determining significant components of most workers' wages and working conditions. The significance of this regulatory role grew as the system became more centralised, especially 
from the 1960s to the 1980s. The processes of conciliation and arbitration also became intertwined with collective bargaining and the exercise of market power by employers and unions (Niland, 1978; Isaac, 1989). Buoyant economic times, for example, allowed workers and unions to make gains through bargaining outside the arbitration system, while a weaker economy often saw employers using the arbitration system to make gains. Finally, the operation of the system varied substantially from industry to industry, with the form and extent of mediation differing considerably (Perlman, 1954, Walker, 1970).

Complexities aside, the compulsory conciliation and arbitration system administered by industrial tribunals was broadly accepted by all major stakeholders. As a result, the many political controversies surrounding it, and the many legislative changes that followed, focused mostly on how the system operated rather than whether the system should be abandoned (see Bennett, 1994: Chaps. 2 and 4).

\section{Changes in recent decades}

This acceptance changed in the second half of the 1980s when employer groups - especially in the export and small business sectors-began to challenge the system (HR Nicholls Society, 1986, Dabscheck, 1995). A consensus amongst employers demanding major reform emerged in the early 1990s (Sheldon \& Thornthwaite, 1997). Around the same time, trade unions, which had traditionally been pragmatic supporters of the system, also turned against it (Briggs, 2001). Political parties representing these interests fell into line and a new legislative regime followed.

In broad summary, the system that replaced compulsory conciliation and arbitration from the early 1990s onwards was essentially one of enterprise-level collective bargaining, underwritten by a suite of minimum standards. This arguably ended the exceptionalism of Australian industrial relations and brought the system much closer to its counterparts in Anglo-American countries, like the UK, USA, Canada and New Zealand (Colvin \& Darbishire, 2013).

At the same time, a number of peculiarities in the Australian system-including the status and role of industrial tribunals - remain unusual compared to other countries.

The industrial tribunals continued after the 1990s in broadly similar institutional form in the new system, including many of the same individuals retaining their positions. However, the functions of the tribunals changed dramatically (Stewart, 2016). Their role in determining substantive rules of the employment relationship was confined to the setting of minimum standards. The loss of this regulatory role and the new decentralisation of the system meant that the tribunals' dispute resolution function focused almost solely on the workplace level. The main focus of the tribunals became individual disputes rather than collective disputes. With respect to collective disputes, the tribunals no longer enjoyed the power to conciliate and ultimately arbitrate compulsorily. Rather, their involvement focused on procedural aspects of collective bargaining and-except in exceptional circumstances-a voluntary role in conciliating and arbitrating collective disputes at the invitation of the parties. 


\section{Move to voluntary mediation}

The role of the tribunals-evident in the NSW trains case at the beginning of the chapter-deserve further attention. Under the Fair Work Act 2009, the federal tribunal is charged with regulating several procedural aspects of collective bargaining. This amounts to the resolution of disputes over how the process of collective bargaining is conducted rather than disputes over the outcomes of bargaining. There are three main examples.

First, as in several other Anglo-American countries, there is a legislative obligation on the parties to bargain 'in good faith' with each other. The Commission can define the boundaries of bargaining (via 'scope' orders) and hear complaints about behavior to the contrary and may make orders obliging the parties to change their behavior and/or declare majority representation status where trade unions are challenged (Bukarica \& Dallas, 2012). Such applications have become part of the tactics in collective bargaining (Pekarek, Landau, Gahan, Forsyth \& Howe, 2017), especially in highly adversarial situations like the NSW trains case.

Second, industrial action by either unions or employers is not permitted during the operation of a collective agreement. Action is only 'protected' from legal sanction during the period between the end of one agreement and the commencement of another. It is the role of the Commission, as occurred in the NSW trains case, to determine when 'protected action' is permitted. It is also the role of the Commission, in rare situations, to order the suspension or termination of industrial action (McCrystal, 2009). The NSW trains case is one such rare example.

Third, collective agreements can only become legally enforceable if approved by the Commission, which must ensure they meet procedural requirements set out in the Fair Work Act. Once a final agreement is reached, including a successful ballot of employees, it must be lodged with the Commission and formally approved (Stewart, Forsyth, Irving, Johnstone, \& McCrystal, 2016: Chap. 14). It then becomes a publicly available document.

The role of the Fair Work Commission in other aspects of collective dispute resolution is (with very few exceptions) voluntary, granted to it by one or more of the parties. In interest disputes, one of the parties engaged in negotiating a collective agreement may seek conciliation by the tribunal if bargaining reaches an impasse, as occurred in the NSW trains case, although the consent of both is needed for voluntary arbitration of such disputes (see Stewart et al., 2016: 913-914).

In rights disputes, the Act makes it mandatory for every collective agreement to include a disputes procedure. The regulations issued under the Act also provide a standard dispute resolution clause, which will be inserted if the parties do not agree on their own. The choice of 'dispute resolution provider' is therefore left to the parties. The parties could nominate a private provider, but the vast majority of agreements nominate the Fair Work Commission (see Stewart et al., 2016: 166, 374-376). 


\subsubsection{Who Can Act as Mediator?}

\section{Members of industrial tribunals}

Given the long-term dominance of mediation by industrial tribunals in Australia, the most important mediators by far have always been members of these tribunals. What does this mean? What are 'tribunals' and who can become a member of a tribunal in Australia?

Answers to these questions changed over time and varied between jurisdictions. In the early years of the compulsory conciliation and arbitration system, the tribunals were courts, whose members were therefore judges or held the same status as judges, despite performing a wider range of conciliation and arbitration functions. Individual members of the Fair Work Commission are appointed under the Act by the Governor-General (Section 626). This means that each member has considerable autonomy because he/she holds a statutory position and is essentially responsible to the Governor-General rather than the President of the Commission. While this leaves much freedom for tribunal members to develop their own approaches towards dispute resolution, there are also many mechanisms (formal and informal) used to coordinate and review the actions of individual members and ensure a degree of consistency between them.

At 30 June 2017, there were 44 members of the Fair Work Commission, at five levels of appointment: President (1), Vice-President (2), Deputy President (14), Commissioner (22) and Minimum Wage Panel Member (5). There were also 5 members of State tribunals holding joint appointments with the Fair Work Commission (Fair Work Commission, 2017). The qualifications required of appointees vary according to the level of appointment, but the first three (more senior) categories can be judges (or former judges) of a court. Only the President's position holds the same status as a federal court judge. All categories, however, are required to have 'knowledge of, or experience in, one or more of the following fields: (a) workplace relations; (b) law; or (c) business, industry or commerce' (Section 623). Tribunal members have invariably been highly experienced practitioners before taking up their appointments, familiar with the processes of conciliation, mediation and arbitration. Beyond their personal experience, however, there is no systematic or mandatory training for tribunal members, although they can seek to advance their own professional development.

Both consistency and expertise are reinforced by the tradition of the 'panel' system, whereby a small group of tribunal members is allocated to work on all matters related to specific industries. In the NSW trains case, members of the Transport Panel were responsible for hearing the various applications and dealing with them. This also allows tribunal members to get to know the parties, (individuals as well as the organisations), and their specific interests and concerns, providing a better grounding on which to conciliate or mediate.

There was once a convention that nominations by the government of the day for appointment to the tribunals were alternately from employer, union, and government backgrounds. However, recent years have seen a politicisation of the appointments, with conservative governments nominating candidates with employer backgrounds 
and Labor government giving preference to union officials (see Stewart et al., 2016: 149). Despite this, there is a strong tradition — broken by a few - that past allegiances are put aside once individuals assume their appointments. This tradition-along with a number of substantive legal protections (Acton, 2011: 589)-is consistent with the tribunal's reputation for independence and reinforces its legitimacy.

The processes of the tribunal are often quite formal and very public, especially when engaged in arbitration. There are public hearings, transcripts of submissions, and published decisions which provide reasons for the decisions. These published decisions provide some grounds for consistency between the various tribunal members through a loose system of 'precedence', similar to the decision-making processes of a common law court. As well as published decisions, detailed annual reports by the tribunals are presented to parliament. This combination of sources means that many aspects of the tribunals' activities have been well researched.

Conciliation is more private. The processes by which tribunal members deal with the parties are more informal and they remain 'behind closed doors'. The outcomes are only made public if they produce formal orders or recommendations by the Commission or they lead to an agreement between the parties that requires formal approval. The NSW trains case could only be written using publicly available information and talking to informed observers. This feature of conciliation makes research more difficult and there are few Australian studies of how conciliation works.

\section{Other kinds of mediator}

Private mediators of collective labour conflict operate in Australia, although they are relatively new, and rare.

Since the 1970s and 1980s, supported by legislation, conciliation has spread from use primarily in the industrial relations context into diverse areas such as family law, commercial law and discrimination, and expanded to encompass other 'alternative dispute resolution' processes (Spencer \& Altobelli, 2005: pp. 3, 107). A recent industry study of 'Alternative Dispute Resolution Services in Australia' argued that the provision of such services was dominated by lawyers and singleperson consulting firms, estimating 3610 enterprises employing 6316 individuals in 2017-2018 (IBISWORLD, 2018: 26). A reading of this report, however, suggests that the activities of these Alternative Dispute Resolution (ADR) providers lie mostly in areas such as family law and commercial disputes, rather than industrial relations. To the extent that they operate within industrial relations, they seem to have been confined mostly to the resolution of individual disputes, for example in relations to discrimination, rather than collective disputes.

Employment law firms acting as mediators in collective disputes face a tough road to establish and maintain an appearance of independence, because they are almost always paid by one party only. ADR consultants may have expertise in other domains, but without experience in the highly specialised domain of industrial relations, would struggle to gain credibility.

There are some exceptions - consultants with both mediation and industrial relations expertise, who are able to build trust with all parties. For example, in 
1996 a joint venture was established between Restructuring Associates Inc., the US consulting firm central to the transformative interest-based bargaining process between the significant healthcare organisation Kaiser Permanente and its unions, and the Australian law firm Corrs Chambers Westgarth. A key part of the joint venture's practice was to support interest-based collective bargaining, and to assist unions and management in the design of more collaborative processes and governance arrangements. CoSolve is another exception: a small firm of principals with the mediation and negotiation expertise to work with unionised firms to settle and prevent disputes, and improve relationships (for cases, see Macneil \& Bray, 2013; Bray \& Macneil, 2015; Macneil \& Bray, 2015). There are a few other studies which mention private mediators (see Van Gramberg, 2006; Forbes-Mewett, G. Griffin, J. Griffin, \& McKenzie, 2005; Riley, 2009; Forsyth, 2012).

However, despite these exceptions, industrial tribunals dominate collective dispute resolution in Australia.

\subsubsection{How Common Is the Mediation of Collective Conflict?}

Mediation of collective conflict was very common during the operation of the old system of compulsory conciliation and arbitration. Unions were generally strong, enjoying high levels of membership and considerable capacity to exercise both industrial and political power. Employers were reactive, with all but the largest generally relying on employer associations to deal with unions through the tribunals rather than developing professionalism amongst managers and effective workplace strategies. The system was therefore highly adversarial, with many disputes, which ranged from large highly damaging disputes at an industry or even national level to a myriad of small disputes at a workplace level reflecting poor institutional arrangements.

Despite the institutionalised adversarialism, there was a perception that these arrangements had at least the comfort of the known. The union officials, industrial relations (IR) managers, employer association representatives and tribunal members who worked within this system were part of the "IR Club" (Henderson, 1983). While the term was coined as a criticism, for many members of the club there were advantages in familiar rules of engagement: only major disputes had the potential to generate real shocks. For the most part, the tribunal was able to manage the conflict to an accepted, if not always highly satisfactory, conclusion.

From the 1990s onwards, these traditional elements of Australia's system changed significantly, in a context of increasingly neoliberal public policies and more intensely competitive product markets. The decline of the union movement was precipitous. Aggregate union membership fell from around 50\% for much of the 20th century to $30 \%$ in 1997 and then to $15 \%$ by 2016 . The industrial and political power of unions declined correspondingly, although this was uneven across the workforce and unions remained influential in some industries/enterprises. Many employers became openly anti-union, whilst also becoming more professional and learning to deal more effectively with their own workforces. All political parties became less sympathetic 
towards unions and collectivism in industrial relations and labour laws became more restrictive.

In this context, the number, volume and impact of industrial disputes declined dramatically and mediation was therefore far less common (Harley, 2004). For example, the average annual number of working days lost through industrial disputes per one thousand employees across all industries in Australia fell from 56.4 in the five-year period 1985-89 to 22.2 in the 1995-99 period and 4.1 in 2010-14 (see Bray et al., 2018: 428). It continued at these very low levels thereafter. Again, there were variations between industries, but the opportunities for tribunals to become involved in mediating collective disputes were reduced correspondingly. The explanation may be that, in some organisations, industrial relations have improved: it is more likely that opportunities for expressing collective voice have declined.

Statistics on the activities undertaken by industrial tribunals are available through their annual reports. They reveal major shifts in the workload of tribunal members over the years, most conspicuously from the resolution of collective disputes to individual disputes and non-dispute matters (see Acton, 2011: 586-589). The Commission's President characterised this trend in these terms:

[There were] ... 34,152 applications lodged in 2014-2015... Twenty years ago, about twothirds of the applications lodged with the Commission were collective in nature. The remaining one-third were comprised of applications lodged by individuals... By 2014-2015 this situation had largely been inverted, with $67 \%$ of applications lodged by individuals and $33 \%$ lodged in relation to collective matters. (Ross, 2016: 406)

Of those activities that do relate to collective arrangements, a large proportion relate only to approval of collective agreements and few actually involve the mediation of disputes.

\subsubsection{At What Stage Does Mediation Take Place?}

The question of when industrial tribunals become involved in the mediation of collective labour conflicts is largely determined by the statutes under which they operate and, in most Australian situations, involvement has been confined to reactive intervention after a dispute has commenced. The NSW trains case study is typical, in that the tribunal members only became involved when the parties could not complete negotiations by themselves. Correspondingly, more proactive intervention by tribunals to prevent conflict and promote cooperative relationships is relatively rare. Also rare is subsequent intervention aimed at reconciliation and/or the re-building of trust after disputes. This is ironic because legislation (especially in the federal jurisdiction) has always defined the tribunals' role in terms of the 'prevention and settlement' of industrial disputes, and the promotion of cooperation has often been a stated object of federal law (see Bray et al., 2017: Chap. 4).

There have been some devices created either by the federal parliament or by the tribunals themselves in an attempt to encourage more proactive/early intervention. 
One was the creation of 'paper disputes' under the old compulsory conciliation and arbitration system (Bray et al., 2017: 59). This involved unions serving exaggerated demands on employers and then using employers' inevitable refusal as a basis for notifying a dispute to the federal tribunal; the gap between the union demands and the employer's offer was called the 'ambit' of the dispute. This established the legal jurisdiction necessary for the tribunal to intervene-technically until the 'dispute' was settled - even though there was no actual industrial action or even serious hostility between the parties. This meant that the parties could gain the ongoing assistance from the tribunal until the ambit was extinguished, potentially preventing actual disruptions to work from emerging. Another example was the 'panel system' for allocating disputes amongst tribunal members, introduced in the early 1970s but continuing under the Fair Work Act (Bray et al., 2017: 60), and described above. Again, this potentially contributed to a longer-term and more proactive approach to the prevention of disputes and the promotion of cooperation. Such devices, however, were modest initiatives in the broader scheme of things, while their impact on the prevention of disputes and the promotion of cooperation were never systematically assessed.

Some of the State laws were less restrictive of the tribunal's activities, allowing them to operate more proactively, if they so choose, and to become involved in relations between employers and unions before disputes became serious. A leading example comes from the Hunter region of New South Wales, where a number of region-specific contingencies came together to support a system in which local tribunal members worked in an on-going way with employers and unions to build cooperative relationships (Bray et al., 2017: Chap. 6). The most long-running case was large construction projects in the region, where from the 1980s onwards tribunal members became involved in each project before it began and almost supervised industrial relations until its completion, meeting regularly with the parties, hearing reports on progress and mediating any disputes that occurred (ibid.: Chap. 7). The outcomes for clients, contractors and employees were excellent. Other cases during the 2000s involved Hunter-based tribunal members intervening in individual enterprises to facilitate the negotiation of collective agreements or working with the parties to introduce workplace change and/or or improve relationships, to the benefit of all participants (ibid.: Chaps. 8 and 9). These (highly successful) interventions, however, were driven mainly by the personal styles of the tribunal members involved rather than by legislative fiat or tribunal policy.

A more systematic approach came later at federal level through legislative amendment in mid-2013, taking effect at the beginning of 2014, which led to the federal industrial tribunal (the Fair Work Commission) going beyond its more traditional reactive approach to develop a new jurisdiction focused on more proactively 'promoting cooperative and productive workplace relations and preventing disputes' (Stewart et al., 2014). Referred to as 'New Approaches', this program is completely voluntary. It began with just two tribunal members undertaking pilot cases in which they were invited by employers and unions wishing to adopt a more cooperative approach, to work with them in on-going projects (Bray and Macneil, 2015). In one state-owned water utility, this involved the tribunal member holding relation- 
ship workshops to review past hostilities and plan the introduction of new more cooperative arrangements, training the parties in the skills they required and providing periodic advice on how to implement the new arrangements (Bray et al., 2017: Chap. 11). Another pilot case took place at a manufacturing organisation in danger of closure. The tribunal member provided behind-the-scenes advice to both senior managers and union leaders and oversaw a framework in which the parties worked together, although the day-to-day training and mediation of minor disputes was undertaken by private consultants (Macneil \& Bray, 2015).

The success of the pilot cases demonstrated the value of the New Approaches program and the President of the Commission gradually expanded the capacity of the tribunal to deliver this type of mediation (through training programs for tribunal members and the provision of administrative support) and publicised its considerable achievements. By September 2017, 44 New Approaches cases had been initiated, involving 16 different tribunal members (Bray et al., 2017: 180-181). This new program is therefore growing, but remains new and confined to a small number of unionised workplaces. Whether it can be applied in non-union workplaces or individual disputes remains to be seen.

\subsection{Evaluating the Effectiveness of Mediation}

The effectiveness of mediation in Australia is assessed less by private mechanisms on a case-by-case basis than by broader political judgment of the system as a whole. Indeed, the dominant role of the state in mediation in Australia and the public nature of the mediation arrangements makes it a focus of public policy debate, much of which has been highly partisan (Bennett, 1994: Chap. 2). As already mentioned, for most of the 20th century, this debate focused on the details of how the compulsory conciliation and arbitration system operated rather than any questioning of its legitimacy. This changed to some degree from the late 1980s, when some employers in particular saw tribunals as illegitimate 'third parties' to the employment relationship that prevented direct engagement between employers and individual employees (Cooper \& Ellem, 2008; Mitchell, Taft, Forsyth, Gahan, \& Sutherland, 2010). This sentiment found expression in some elements of the conservative, neoliberal agenda of the Coalition government led by Prime Minister Howard between 1996 and 2007. However, both the broad support of 'public opinion' as well as the uncertainties of parliamentary politics allowed the tribunals to survive and the Fair Work regime from 2009 onwards saw the tribunals regain an important role in the industrial relations system (Stewart, 2016).

The most recent period has also seen the emergence of new methods by which the tribunals attempt to retain the support of stakeholders and the public more generally. The current President of the Fair Work Commission — appointed in 2012_formalised and made public the tribunal's strategic plan, which was called 'Future Directions'. Central to this initiative were the concepts of accountability and 'public value': 
My starting proposition is that the Commission serves the community through the provision of an accessible, fair and efficient dispute resolution service and that in delivering that service, we are accountable to the community. Part of that accountability involves regularly reporting on the Commission's performance. At its core, reporting is about identifying the public value of the institution and communicating to stakeholders and the public that their expectations are being met. (Ross, 2016: 403; see also Ross, 2012)

There were four component parts of the Commission's strategy:

- promoting fairness and improving access to the tribunal by interested parties;

- efficiency and innovation in the way the tribunal operated;

- increasing the accountability of the tribunal, especially by making its operation more transparent; and

- promoting productivity and engaging with industry.

Overall, the various innovations within these four areas-most of which focus on the tribunal's newer jurisdictions involving individual rather than collective disputes (see also Van Gramberg, Teicher, \& Bamber, 2016)—were focused on demonstrating the effectiveness of the tribunal to the general public as well as major stakeholders, like politicians, employers and employer associations, and trade unions. The success of these efforts remains to be seen, but there is no doubt they indicate a different approach to that of the FWC's predecessors. As New Approaches becomes a more established stream of tribunal activity, it will be interesting to see how the Fair Work Commission seeks to measure, in more detail and over time, the public value that this form of mediation creates.

\subsection{Conclusions}

Despite changes in the last three decades which have brought it more into line with its Anglo-American counterparts, the Australian industrial relations system retains some of its exceptionalism. Part of this involves the central role of industrial tribunals in the system, sustained by the respect and legitimacy they have gained through their long history and perceived independence. Other types of mediators have not been seen in Australia as genuine alternatives to the tribunals.

Despite their continuing prominence, the role of Australia's tribunals is changing. The decline of unions and rise of individual employment rights mean that tribunals are increasingly focused on the resolution of individual disputes and the determination of minimum standards. The corresponding reduction in collective conflict means that mediation of collective labor disputes is less important than it once was. In this sense, the tribunal's role in the dramatic NSW trains dispute, discussed at the beginning of the chapter, is now atypical.

Perhaps the most interesting recent development is the move towards more proactive intervention by tribunals and the use of interest-based bargaining techniques to promote cooperation and improved productivity within unionised workplaces. The early success of the Fair Work Commission's New Approaches program is promising, 
and there is reason to be believe that Australia's industrial tribunals are especially well-placed to perform such a role, even compared to their counterparts in other countries. The expansion of this program, however, will require determination and specialist resources given the dominance of adversarialism in Australian industrial relations and politics.

Along with their traditional conciliation activities, the federal tribunals New Approaches initiative and similar State-based programs have provided further opportunities for members to mediate collective labour disputes. For as long as legislation in Australia provides a role for unions in collective bargaining, and in sectors where unions still have sway, the tribunal's expertise and perceived independence is likely to ensure its continued role in this type of mediation.

\section{References}

Acton, J. (2011). Fair work Australia: An accessible, independent umpire for employment matters. Journal of Industrial Relations, 53(5), 578-595.

Bennett, L. (1994). Making labour law in Australia. Sydney: Law Book Company.

Bray, M., \& Macneil, J. (2015). Facilitating productive workplace cooperation: A case study of Sydney Water and the ASU Water Division, Fair Work Commission, Melbourne, p. 6. https://www. fwc.gov.au/documents/documents/engagement/case-studies/syd-water-case-study-2015.pdf.

Bray, M., Macneil, J., \& Stewart, A. (2017). Cooperation at work: How tribunals can help transform workplaces. Sydney: Federation Press.

Bray, M., Waring, P., Cooper, R., \& Macneil, J. (2018). Employment relations: Theory and practice (4th ed.). Sydney: McGraw Hill.

Briggs, C. (2001). Australian exceptionalism: The role of trade unions in the emergence of enterprise bargaining. Journal of Industrial Relations, 43(1), 27-43.

Bukarica, A., \& Dallas, A. (2012). Good faith bargaining under the Fair Work Act 2009. Sydney: Federation Press.

Colvin, A., \& Darbishire, O. (2013). Convergence in industrial relations institutions: The emerging Anglo-American model? Industrial and Labor Relations Review, 66(5), 1047-1477.

Cooper, R., \& Ellem, B. (2008). The neoliberal state, trade unions and collective bargaining in Australia. British Journal of Industrial Relations, 46(3), 532-554.

Dabscheck, B. (1995). The struggle for Australian industrial relations. Melbourne: Oxford University Press.

Fair Work Commission. (2017). Annual report 2016-17: New approaches to workplace relations. Melbourne: Fair Work Commission.

Foenander, O. (1959). Industrial conciliation and arbitration in Australia. Sydney: Law Book Co.

Forbes-Mewett, H., Griffin, G., Griffin, J., \& McKenzie, D. (2005). The role and usage of conciliation and mediation inn dispute resolution in the Australian industrial relations commission. Australian Bulletin of Labour, 31(2), 171-189.

Forsyth, A. (2012). Workplace conflict resolution in Australia: The dominance of the public dispute resolution framework and the limited role of ADR. International Journal of Human Resource Management, 23(3), 476-494.

Harley, B. (2004). Managing industrial conflict. In J. Isaac \& S. Macintyre (Eds.), The new province for law and order: 100 years of Australian industrial conciliation and arbitration (pp. 316-354). Melbourne: Cambridge University Press.

Henderson, G. (1983). The industrial relations club. Quadrant, 27(9), 21-29.

HR Nicholls Society. (1986). Arbitration in contempt. Melbourne: HR Nicholls Society. 
IBISWORLD. (2018). Alternative dispute resolution services in Australia: IBISWORLD industry report OD4116 (privately commissioned by the University of Newcastle).

Isaac, J. (1989, September). The Arbitration Commission: Prime Mover or Facilitator. Journal of Industrial Relations, 31(3), 407-427.

Isaac, J., \& Macintyre, S. (Eds.). (2004). The new province for law and order: 100 years of Australian industrial conciliation and arbitration. Melbourne: Cambridge University Press.

Isaac, J. E., \& McCallum, R. C. (1992). The neutral and public interests in resolving disputes in Australia. Comparative Labor Law Journal, 13(4), 380-409.

Macintyre, S., \& Mitchell, R. (Eds.). (1989). Foundations of arbitration: The origins and effects of state compulsory arbitration, 1890-1914. Melbourne: Oxford University Press.

Macneil, J., \& Bray, M. (2013). Third party facilitators in interest-based negotiation: An Australian case study. Journal of Industrial Relations, 55(5), 699-722.

Macneil, J., \& Bray, M. (2015). Aiming for collaborative transformation: A case study of Orora Fibre Packaging and the AMWU Printing Division, Fair Work Commission, Melbourne. https:// www.fwc.gov.au/documents/documents/engagement/case-studies/orora-case-study-2015.pdf.

McCrystal, S. (2009). A new consensus: The coalition, the ALP and the regulation of industrial action. In A. Forsyth \& A. Stewart (Eds.), Fair work: The new workplace laws and the work choices legacy (pp. 141-163). Sydney: The Federation Press.

Mitchell, R., Taft, D., Forsyth, A., Gahan, P., \& Sutherland, C. (2010). Assessing the impact of employment legislation: The Coalition's Labour Law Program, 1996-2007. Australian Journal of Labour Law, 23(3), 274-301.

Niland, J. (1978). Collective bargaining and compulsory arbitration in Australia. Sydney: NSW University Press.

Pekarek, A., Landau, I., Gahan, P., Forsyth, A., \& Howe, J. (2017). Old game, new rules? The dynamics of enterprise bargaining under the Fair Work Act. Journal of Industrial Relations, 59(1), 44-64.

Perlman, M. (1954). Judges in industry. Melbourne: Melbourne University Press.

Riley, J. (2009). Workplace dispute resolution under the Fair Work Act: Is there a role for private alternative dispute resolution providers? Australian Dispute Resolution Journal, 20(4), 236-243.

Ross, I. Justice. (2012). Promoting tribunal excellence. Journal of Judicial Administration, 21(3), $135-145$.

Ross, I. Justice. (2016). Future directions: Enhancing the public value of the Fair Work Commission. Journal of Industrial Relations, 58(3), 402-418.

Sheldon, P., \& Thornthwaite, L. (Eds.). (1997). Employer associations and industrial relations change. Sydney: Allen \& Unwin.

Spencer, D., \& Altobelli, T. (2005). Dispute resolution in Australia: Cases, commentary and materials. Pyrmont: Law Book Co.

Stewart, A. (2016). Continuity and change in Australian Labour Regulation: Work choices, fair work and the role of the "Independent Umpire". In K. Hancock \& R. D. Lansbury (Eds.), Industrial relations reform: Looking to the future (pp. 40-65). Sydney: Federation Press.

Stewart, A., Bray, M., Macneil, J., \& Oxenbridge, S. (2014). "Promoting cooperative and productive workplace relations": Exploring the Fair Work Commission's new role. Australian Journal of Labour Law, 27(3), 258-280.

Stewart, A., Forsyth, A., Irving, M., Johnstone, R., \& McCrystal, S. (2016). Creighton \& Stewart's Labour Law. Sydney: Federation Press.

Van Gramberg, B. (2006). Managing workplace conflict. Sydney: Federation Press.

Van Gramberg, B., Teicher, J., \& Bamber, G. (2016). Reshaping the role of the tribunal as third party in Australian workplace conflict resolution. In R. Saundry, P. Latrielle, \& I. Ashman (Eds.), Reframing resolution (pp. 237-263). Palgrave Macmillan, London.

Walker, K. (1970). Australian industrial relations systems. Melbourne: OUP.

Walker, K. (1984). The development of Australian industrial relations in international perspective. In W. Howard (Ed.), Perspectives on Australian industrial relations (pp. 1-19). Melbourne: Longman Cheshire. 


\section{Sources for NSW Trains case}

Anonymous. (2018a, January 25). Rail strike off as FWC issues suspension order. Workplace Express. https://www.workplaceexpress.com.au/n106_news_selected.php? $\mathrm{R}=2 \&$ act $=2 \&$ stream $=$ $2 \&$ selkey $=56417 \& \mathrm{hlc}=2 \& \mathrm{hlw}=$, sourced February 15, 2018.

Anonymous. (2018b, February 8). Sydney train workers offered 3pc pay rise as part of new offer to rail union. $A B C$ News. http://www.abc.net.au/news/2018-02-08/nsw-rail-workers-get-new-payoffer/9407290, sourced February 16, 2018.

Fair Work Ombudsman. (2017). Industrial action. Last updated July 2017. https://www.fairwork. gov.au/how-we-will-help/templates-and-guides/fact-sheets/rights-and-obligations/industrialaction\#termination, pp. 1-4.

O'Sullivan, M., \& Visentin, L. (2018, January 25). Sydney escapes commuter chaos after rail workers forced to abandon strike. Sydney Morning Herald. http://www.smh.com.au/nsw/sydneyescapes-commuter-chaos-after-rail-workers-forced-to-abandon-strike-20180125-h0obpq.html, sourced February 15, 2018.

RBTU. (2018, January 12). Sydney \& NSW Trains results—prepare for action! Loco Express. http:// locoexpress.com.au/sydney-nsw-trains-results-prepare-action/.

Sydney Trains, NSW Trains and the Australian Rail, Tram and Bus Industry Union, The Association of Professional Engineers, Scientists and Managers, Australia. (2017). Decision by Commissioner Cambridge, Matter nos. B2017/1116-1127, Fair Work Commission, 23 November. http://classic.austlii.edu.au/cgi-bin/sinodisp/au/cases/cth/FWC/2017/6158. $\mathrm{html}$ ?stem=0\&synonyms $=0 \&$ query $=$ sydney $\% 20$ trains $\% 20$ and $\% 20$ protected $\% 20$ action, sourced February 15, 2018.

Sydney Trains, NSW Trains and the Australian Rail, Tram and Bus Industry Union, The Association of Professional Engineers, Scientists and Managers, Australia. (2018). Transcript of proceedings before SDP Hamberger, Matter no. B2018/50, Fair Work Commission, 25 January. https:// www.fwc.gov.au/documents/documents/transcripts/20180125_b201850.htm, sourced February $15,2018$.

Open Access This chapter is licensed under the terms of the Creative Commons Attribution 4.0 International License (http://creativecommons.org/licenses/by/4.0/), which permits use, sharing, adaptation, distribution and reproduction in any medium or format, as long as you give appropriate credit to the original author(s) and the source, provide a link to the Creative Commons license and indicate if changes were made.

The images or other third party material in this chapter are included in the chapter's Creative Commons license, unless indicated otherwise in a credit line to the material. If material is not included in the chapter's Creative Commons license and your intended use is not permitted by statutory regulation or exceeds the permitted use, you will need to obtain permission directly from the copyright holder.

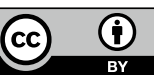

